\title{
ANALISIS KUALITAS RUMPUT LAUT Gracilaria verrucosa DI TAMBAK KABUPATEN KARAWANG, JAWA BARAT
}

\section{QUALITY ANALISYS OF SEAWEED Gracilaria verrucosa IN KARAWANG DISTRICT PONDS, WEST JAVA}

\author{
Waluyo $^{1}$, Aef Permadi ${ }^{2}$, Norma Aprilia Fanni ${ }^{3}$, Angky Soedrijanto ${ }^{3}$ \\ 1. Staf Pengajar Departemen Teknologi Kelautan, Politeknik KP Karawang \\ 2. Staf Pengajar Departemen Pengolahan Hasil Perikanan, Politeknik KP Karawang \\ 3. Fakultas Perikanan Universitas Islam Lamongan \\ J1. Veteran no. 53A Lamongan Phone/Fax. 0322_324706 \\ *E-mail : waluyo_uyo@yahoo.com
}

\begin{abstract}
ABSTRAK
Rumput laut adalah salah satu komoditas perikanan yang perlu mendapatkan perhatian khusus terkait kualitas rumput laut untuk mendapatkan agar-agar berkualitas tinggi. Gracilaria verrucosa merupakan jenis rumput laut yang paling utama sebagai sumber penghasil agar (agarofit) yang sebagian besar dimanfaatkan baik dikonsumsi secara langsung maupun untuk kebutuhan industri. Penelitian ini bertujuan untuk mengetahui kualitas rumput laut yang meliputi kandungan rendeman agar, kadar air, kadar abu, serat kasar, Clean Anhydrous Weed (CAW), pengotor, viskositas, gel streght, derajat putih serta kadar sulfat rumput laut yang dibudidaya di tambak Kabupaten Karawang, Jawa Barat, dengan pendekatan analisis diskriptif berdasarkan hasil uji kimia di laboratorium. Penelitian ini dilakukan pada Bulan September 2017, dengan mengambil sample rumput laut dan kualitas air tambak sebanyak 15 stasiun secara acak. Berdasarkan hasil analisis kualitas agar-agar Gracilaria verrucosa di Kabupaten Karawang menunjukkan bahwa secara umum kualitas cukup baik. Kadar sulfat hanya mencapai $4.82 \%$ yang artinya bahwa zat pengotor dalam kandungan agar-agar relative rendah, yaitu di bawah $6 \%$. Akan tetapi terdapat beberapa parameter yang kualitasnya cukup tinggi yaitu viskositas dan gel strenght. Viskositas agar mencapai $201.6 \mathrm{cps}$ dan kekuatan gel strenght $356.76 \mathrm{~g} / \mathrm{cm}^{2}$.
\end{abstract}

Kata kunci : agar, Gracilaria verrucosa, kualitas rumput laut, Kabupaten Karawang

\section{PENDAHULUAN}

Rumput laut spesies Gracilaria verrucosa merupakan salah satu rumput laut jenis alga merah genus Gracilariaceae (Rhodophyta) yang cukup melimpah secara alamiah di laut tropis maupun subtropis. Gracilaria verrucosa merupakan jenis rumput laut utama sebagai sumber penghasil agar (agarofit) yang sebagian besar dimanfaatkan baik dikonsumsi secara langsung maupun untuk kebutuhan industri (Pelegrin and Murano 2005). Di Indonesia Gracilaria verrucosa merupakan salah satu jenis rumput laut yang banyak dimanfaatkan sebagai bahan baku industri kesehatan contohnya untuk kosmetik dan obat-obatan (Glicksman 1982).
Kebutuhan rumput laut sebagai bahan baku industri nasional setiap tahun terus meningkat seiring dengan kebutuhan dan inovasi produk makanan berbasis rumput laut (McHugh 2003). Secara alamiah, rumput laut jenis Gracilaria verrucosa memiliki habitat asli di laut, akan tetapi rumput laut jenis ini bersifat euryhaline, artinya bahwa rumput laut Gracilaria verrucosa dapat tumbuh pada kisaran salinitas yang sangat luas, yaitu kisaran antara 5.2-38.1\%o. Dengan demikian rumput laut ini memiliki potensi dan peluang untuk dibudidayakan di perairan tambak dengan karakteristik perairan bersifat payau. Budidaya rumput laut Gracilaria verrucosa di tambak relatif lebih mudah dan tidak memerlukan biaya sarana produksi yang lebih tinggi 
(Anggadiredja 1998). Wilayah pesisir Kecamatan Tirtajaya, Kabupaten Karawang merupakan salah satu daerah pusat budidaya rumput laut Gracilaria verrucosa. Selain sebagai pusat produksi budidaya rumput laut Gracilaria verrucosa, wilayah ini juga sebagai pusat pengepul hasil budidaya rumput laut dari beberapa daerah lain seperti dari Kabupaten Bekasi, Subang dan Indramayu. Hasil produksi rumput laut kering selanjutnya dijual ke PT. Agarindo, Tangerang. Selama ini, para pembudidaya mengontrol kualitas rumput laut kering Gracilaria verrucosa yang sudah siap dijual dengan mengetahui kadar airnya saja, yaitu 14-16\%.

Tujuan dari penelitian ini adalah untuk mengetahui kualitas rumput laut yang dibudidaya di tambak Kecamatan Tirtajaya, Kabupaten Karawang, Jawa Barat. Manfaat penelitian ini adalah diharapkan dapat sebagai bahan rekomendasi dalam perbaikan dan pengelolaan budidaya rumput laut baik secara langsung kepada pembudidaya rumput laut maupun stakeholders terkait.

\section{METODOLOGI}

\section{Waktu dan Lokasi Penelitian}

Penelitian dilaksanakan pada Bulan September 2017 di tambak Kecamatan Tirtajaya, Kabupaten Karawang, Jawa Barat. Pengambilan data primer dilakukan dengan mengambil data kualitas air tambak di 15 titik stasiun secara acak. Peta lokasi penelitian dapat dilihat pada Gambar 1.

Data

Data primer perairan tambak yang diambil secara insitu adalah suhu air tambak, salinitas, $\mathrm{pH}$, oksigen terlarut, kedalaman, dan kecerahan air tambak. Data suhu dan oksigen terlarut diukur menggunakan alat DO meter, salinitas menggunakan refraktometer, $\mathrm{pH}$ menggunakan $\mathrm{pH}$ meter, kedalaman diukur dengan papan skala, dan kecerahan air diukur dengan secchi disk.

Data kualitas air meliuti nitrat, fosfat, dan amoniak yang diambil menggunakan botol sample, kemudian dianalisis di Laboratorium Balai Layanan Usaha Produksi Perikanan Budidaya (BLUPPB) Karawang. Analisis kualitas rumput laut dilakukan di Laboratorium Preservasi dan Pengolahan Hasil Perikanan, Departemen Teknologi Hasil Perairan, Fakultas Perikanan dan Ilmu Kelautan, Institut Pertanian Bogor (IPB). Parameter kualitas air tambak disajikan pada Tabel 1 .

\section{Analisis Data}

Analisis data dilakukan adalah untuk mengetahui kualitas rumput laut, meliputi kandungan rendeman agar, kadar air, kadar abu, serat kasar, Clean Anhydrous Weed (CAW), pengotor, viskositas, gel streght, derajat putih serta kadar sulfat rumput laut. 


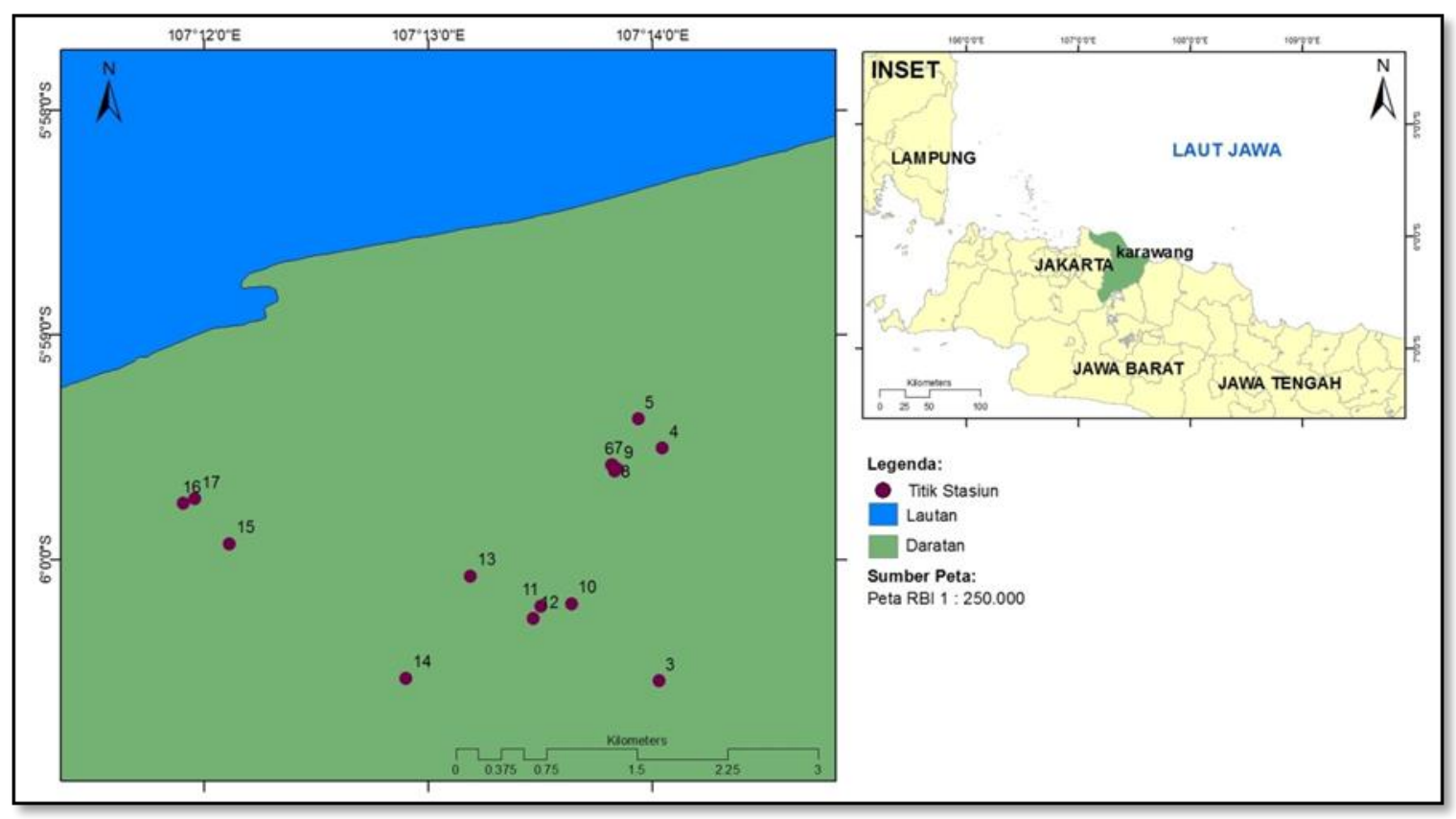

Gambar 1. Peta Lokasi Penelitian di Tambak Kecamatan Tirtajaya, Kabupaten Karawang.

Tabel 1. Parameter Kualitas Air yang diambil

\begin{tabular}{llcll}
\hline No & Parameter & Satuan & Alat & Metode \\
\hline 1 & Suhu perairan & ${ }^{\circ} \mathrm{C}$ & Thermometer & Analisis insitu \\
2 & Salinitas & $\%$ o & Refraktometer & Analisis insitu \\
3 & pH & & pH meter & Analisis insitu \\
4 & DO & $\mathrm{mg} / \mathrm{l}$ & DO meter & Analisis insitu \\
5 & Kecerahan & $\mathrm{m}$ & Secchi disk & Analisis insitu \\
6 & Nitrat $\left(\mathrm{NO}_{3}-\mathrm{N}\right)$ & $\mathrm{mg} / \mathrm{l}$ & Botol sample & Spektrofotometri \\
7 & Fosfat $\left(\mathrm{PO}_{4}-\mathrm{P}\right)$ & $\mathrm{mg} / \mathrm{l}$ & Botol sample & Spektrofotometri \\
8 & Aminia $\left(\mathrm{NH}_{3}\right)$ & $\mathrm{mg} / \mathrm{l}$ & Botol sample & Spektrofotometri \\
9 & Kedalaman & $\mathrm{m}$ & Papan skala & Analsisis insitu \\
\hline
\end{tabular}

\section{Analisis Rendemen Agar}

Untuk mengetahui konsentrasi rendemen agar dari sample rumput laut, maka dilakukan ekstraksi rumput laut dan dihitung berdasarkan perbandingan antara berat kering agar hasil ekstraksi dengan berat rumput laut kering dalam bentuk tepung setelah proses pengolahan. Rendeman agar dihitung dengan menggunakan rumus sebagai berikut (Yousefi et al. 2013):

$$
\text { Rendemen }=\frac{W a}{W r} \times 100 \%
$$

Keterangan:

$$
\begin{array}{ll}
\mathrm{Wa} & \text { : berat agar kering }(\mathrm{g}) \\
\mathrm{Wr} & \text { : berat rumput laut kering } \\
& \text { bentuk tepung }(\mathrm{g})
\end{array}
$$

\section{Kadar Air}

Analisis kadar air bertujuan untuk mengetahui jumlah molekul air baik yang tidak terikat (free water) dan terikat yang terkandung dalam suatu produk. Prinsip dari analisis kadar air adalah molekul air dihilangkan melalui pemanasan dengan oven vakum pada suhu berkisar antara 95$100{ }^{\circ} \mathrm{C}$ dengan tekanan udara tidak lebih 
dari $100 \mathrm{mmHg}$ selama 5 jam. Penentuan berat air dihitung secara gravimetri berdasarkan selisih berat sampel sebelum dan sesudah sampel dikeringkan. Kadar air dinyatakan dalam persentase.

Metode analisis kadar air dilakukan berdasarkan SNI 2690:2015. Kadar air dihitung dengan menggunakan rumus :

$$
\text { Kadar air }=\frac{B-C B}{B-A} \times 100 \%
$$

Keterangan :

$$
\begin{array}{ll}
\text { A } & \text { : berat cawan kosong }(\mathrm{g}) \\
\mathrm{B} & \text { : berat cawan }+ \text { sampel awal }(\mathrm{g}) \\
\mathrm{C} & \text { : berat cawan }+ \text { sampel kering }(\mathrm{g})
\end{array}
$$

\section{Kadar abu}

Kadar abu adalah jumlah residu anorganik yang dihasilkan dari pengabuan/pemijaran suatu produk. Analisis kadar abu dilakukan dengan menggunakan metode SNI 2354.1:2010. Prinsip dasar analisis kadar abu adalah sampel diabukan pada suhu $550{ }^{\circ} \mathrm{C}$ dalam tungku pengabuan (furnace) selama 8 jam atau sampai mendapatkan abu berwarna putih. Penetapan berat abu dihitung secara gravimetri. Kadar abu agar dihitung dengan rumus :

$$
\text { Kadar abu }=\frac{B-A}{\text { Berat sample }} \times 100 \%
$$

Keterangan :

$$
\begin{array}{ll}
\text { A } & \text { : berat cawan porselin kosong }(\mathrm{g}) \\
\mathrm{B} & \text { : berat cawan dengan abu }(\mathrm{g})
\end{array}
$$

\section{Serat kasar}

Analisis serat kasar rumput laut bertujuan untuk mengetahui tingkat gel yang terbentuk. Tinggi rendahnya serat kasar sangat berpengaruh pada gel, yang menunjukkan bahwa serat yang tinggi akan menghasilkan gel yang tinggi juga. Metode analisis kandungan serat kasar dilakukan dengan metode gravimetri. Serat kasar dapat dihitung dengan rumus :

Serat Kasar $=$ $\frac{\text { Berat kertas residu-Berat kertas }}{\text { Berat sample }} \times 100 \%$

\section{Clean Anhydrous Weed (CAW)}

Clean anhydrous weed (CAW) merupakan perbandingan berat bersih dan kotor yang diukur pada saat melakukan pencucian rumput laut sebelum diekstraksi untuk menghasilkan agar. Pengukuran CAW dilakukan berdasarkan metode Marine Colloid Modification. Metode analisis CAW dapat diukur dengan rumus (SNI 2690:2015):

$$
\text { CAW }=\frac{\text { Berat rumput laut kering }}{\text { Berat awal rumput laut }} \times 100 \%
$$

\section{Pengotor (Impurities)}

Sampel rumput laut sebanyak $250 \mathrm{~g}$ ditimbang. Rumput laut dipisahkan dari segala jenis kotoran (rumput laut jenis lain, plastik, kerang, garam, pasir, dan benda asing lainnya). Kotoran yang sudah terkumpul kemudian ditimbang.

Perhitungan impurities yaitu (SNI 2690:2015):

$$
\begin{gathered}
\text { Kadar Impuritas }= \\
\frac{\text { Berat kotoran }}{\text { Berat rumput laut awal }} \times 100 \%
\end{gathered}
$$

\section{Ekstraksi Agar}

Proses ekstraksi agar-agar diawali dengan pencucian rumput laut kering sebanyak $100 \mathrm{~g}$, rumput laut yang sudah bersih kemudian direndam dengan asam asetat 3\% selama 3 menit. Rumput laut kemudian dicuci hingga $\mathrm{pH}$ menjadi netral. Ekstraksi agar-agar dilakukan selama 2 jam pada suhu $80{ }^{\circ} \mathrm{C}$ sambil diaduk. Jumlah air yang digunakan adalah 16 kali berat rumput laut kering. Rumput laut kemudian disaring menggunakan kain sring 150 mesh dan filtratnya ditambahkan $\mathrm{KCl} 2 \%$ dari jumlah filtrat sambil diaduk 15 menit. Agar-agar kemudian dijendalkan pada suhu ruang selama 12 jam dan dilanjutkan dengan pembekuan selama 24 jam. Agar-agar yang sudah beku kemudian di thawing dan dikeringkan menggunakan sinar matahari untuk kemudian menjadi agar-agar kering. 


\section{Viskositas}

Mengukur viskositas berdasarkan metode yang dikembangkan dalam Marine Colloids Inc 1977. Viskositas adalah ukuran gaya yang diperlukan untuk menggeser suatu cairan pada satuan kecepatan yang dinyatakan dalam $\mathrm{mPa} . \mathrm{S}$ dan diukur pada suhu tertentu atau tahanan dari suatu cairan untuk mengalir dengan satuan poise $(1$ poise $=100$ centipoise $/ \mathrm{cP})$. Viskositas sampel diukur dengan menggunakan alat viskometer. Viskositas merupakan perbandingan antara tekanan geser suatu cairan. Suspensi koloid dalam larutan dapat meningkat dengan cara mengentalkan cairan sehingga terjadi absorsi dan pengembangan koloid (Glicksman 1982). Viskositas dipengaruhi oleh jenis rumput laut penghasil agar dalam kondisi selama proses panen.

\section{Kekuatan gel}

Kekuatan gel adalah gaya yang dibutuhkan untuk memecah permukaan gel dalam waktu tertentu dibagi jarak yang ditempuh dari agar. Pengukuran kekuatan gel pada agar dilakukan dengan metode KCl-Gel Strength menggunakaan alat texture analyzer. Prinsipnya besar gaya yang dibutuhkan sampai permukaan gel pecah (McHugh 2003).

\section{Derajat putih}

Derajat putih adalah tingkat keputihan atau bahan dalam hal ini sampel agar. Analisis warna dilakukan dengan menggunakan alat Whitenessmeter. Prinsipnya sinar dari sumber sinar direfleksikan dari permukaan sampel dan bertemu di fokus photodioda melalui lenga dan filter ke sumber arus listrik. Sampel yang lebih putih, cahaya yang terefleksi akan lebih banyak sehingga arus listrik yang dibutuhkan menjadi semakin besar dan mengakibatkan nilai yang tertera dimonitor menjadi tinggi.

\section{Kadar sulfat}

Kadar sulfat dalam agar diukur untuk melihat kualiatas agar yang dihasilkan setelah diekstraksi. Prinsip pengukuran kadar sulfat adalah ion sulfat yang bereaksi dengan barium klorida dalam suasana asam akan membentuk suspensi barium sulfat, dengan reaksi : $\mathrm{SO}_{4}{ }^{2-}+\mathrm{BaCl}_{2} \rightarrow$ $\mathrm{BaSO}_{4}+2 \mathrm{CI}$. Berat $\mathrm{BaSO}_{4}$ yang diperoleh ekivalen dengan kadar $\mathrm{SO}_{4}$ dalam sampel agar yang dianalisa. Pengukuran kadar sulfat dilakukan dengan metode gravimetri. Kadar sulfat dapat dihitung dengan rumus (Sukomulyo 1989):

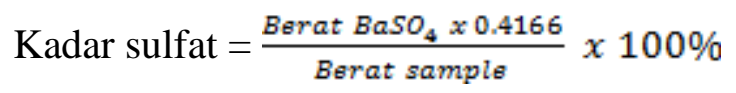

\section{HASIL DAN PEMBAHASAN}

\section{Kualitas Rumput Laut}

Pada penelitian ini untuk mengetahui kualitas dari rumput laut menggunakan beberapa parameter, yaitu rendemen agar, kadar air, kadar abu, serat kasar, Clean Anhydrous Weed (CAW) serta pengotor. Kualitas rumput laut tidak hanya dipengaruhi oleh teknik budidaya, tetapi juga dipengaruhi oleh umur tanam dan kualitas perairan (Mc Hugh 2003). Hasil analisis laboratorium terhadap parameter kualitas rumput laut Gracilaria verrucosa yang ada di Kecamatan Tirtajaya, Kabupaten Karawang ditampilkan pada Tabel 2.

Rumput laut dikatakan bermutu jika rendemen agarnya tinggi. Hasil analisis menunjukkan bahwa rendemen agar yang dibudidaya di tambak Kecamatan Tirtajaya rata-rata sebesar $46 \%$. Menurut FAO (1987) tinggi rendahnya rendemen agar dipengaruhi oleh spesies rumput laut, iklim, dan usia panen. Berdasarkan BSN (1998) rumput laut Gracilaria verrucosa dikatakan bermutu jika kandungan rendemen agarnya lebih dari $25 \%$. Agar merupakan polisakarida yang terakumulasi dalam dinding sel rumput laut penghasil 
agar yang dipengaruhi oleh musim (Armisen and Galatas 2000).

Kualitas rumput laut menurun, bila kadar abu terlalu tinggi. Kadar abu yang dikatakan baik tidak melebihi dari $40 \%$ yang telah distandarkan oleh FAO, dan kadar air tidak mempengaruhi kualitas rumput laut.Akan tetapi berdasarkan beberapa penelitian yang telah dilakukan oleh Cirik et al. (2010) yang mengkaji tentang kualitas rumput laut Gracilaria verrucosa menyatakan bahwa rumput laut yang baik mengandung kadar air antara 10.90-11.71\%. Marinho et al. (2006) juga menyatakan bahwa kadar air yang baik untuk rumput laut $G$. cervicornis sebanyak $14.66 \%$. Begitu juga berdasarkan Ova and Kaykaç (2007) menyatakan kandungan kadar air G. verrucosayang baik bervariasi antara $11.73 \%$ (musim panas) dan $10.67 \%$ (musim gugur). Selain itu, konsentrasi kadar abu pada Gracilaria verrucosa di tambak Kecamatan Tirtajaya mencapai $44.33 \%$, dengan demikian kualitas rumput laut berdasarkan kadar abu termasuk kategori kualitas relatif kurang baik, walaupun nilai kadar bau tidak terlalu jauh berbeda dengan yang distandarkan oleh FAO (1987).

Kadar abu pada tepung agar yang dihasilkan berhubungan dengan kandungan mineral yang terkandung dalam rumput laut yang dijadikan bahan baku.
Kandungan mineral tersebut dapat dipengaruhi oleh keadaan dan juga kondisi perairan asal dari rumput laut dibudidayakan. Semakin lama rumput laut dibudidayakan maka kandungan abunya dapat semakin meningkat karena mineral yang terserap juga akan semakin banyak. Menurut Wenno et al. (2012), bertambahnya umur panen cenderung menyebabkan kadar abu mengalami peningkatan. Rumput laut termasuk bahan pangan yang mengandung mineral cukup tinggi karena kemampuannya dalam menyerap mineral yang berasal dari lingkungannya.

Konsentrasi serat kasar Gracilaria verrucosa dari hasil penelitian adalah $3.43 \%$, dimana standar serat kasar Gracilaria verrucosa yang baik berdasarkan Soegiarto et al. (1978) minimal $10.51 \%$. dengan demikian, serat kasar rumput laut di kecamatan Tirtajaya relatif rendah. Zat pengotor yang terdapat di rumput laut pada lokasi penelitin sebesar $8.44 \%$, dimana syarat yang dipersyaratkan adalah <6\% (FAO, 1987). Dengan demikian, kandungan zat pengotor rumput laut di Kecamatan Tirtajaya relatif tinggi. Grafik perbandingan hasil analisis kualitas rumput laut di Kecamatan Tirtajaya dengan standar yang dipersyaratkan ditampilkan pada Gambar 2.

Tabel 2. Hasil Analisis Data Kualitas Rumput Laut di Kecamatan Tirtajaya

\begin{tabular}{clrcc}
\hline No & \multicolumn{1}{c}{ Parameter } & \multicolumn{1}{c}{ Nilai } & Satuan & Standart \\
\hline 1 & Rendemen agar & 46 & $\%$ & $>25 \%$ (BSN 1998) \\
2 & Kadar air & 11.91 & $\%$ & $10-11 \%$ (Cirik et al. \\
& & & & $2010 ; 14 \%$ (Marinho et \\
& & & & al. 2006) \\
3 & Kadar abu & 44.33 & $\%$ & $<40 \%$ (FAO 1987) \\
4 & Serat kasar & 3.43 & $\%$ & $10.51 \%$ (Soegiarto et al. \\
& & & & $1978)$ \\
5 & Clean Anhydrous & 79.64 & $\%$ & \\
& Weed & & & $<6 \%$ (FAO, 1987) \\
\hline
\end{tabular}




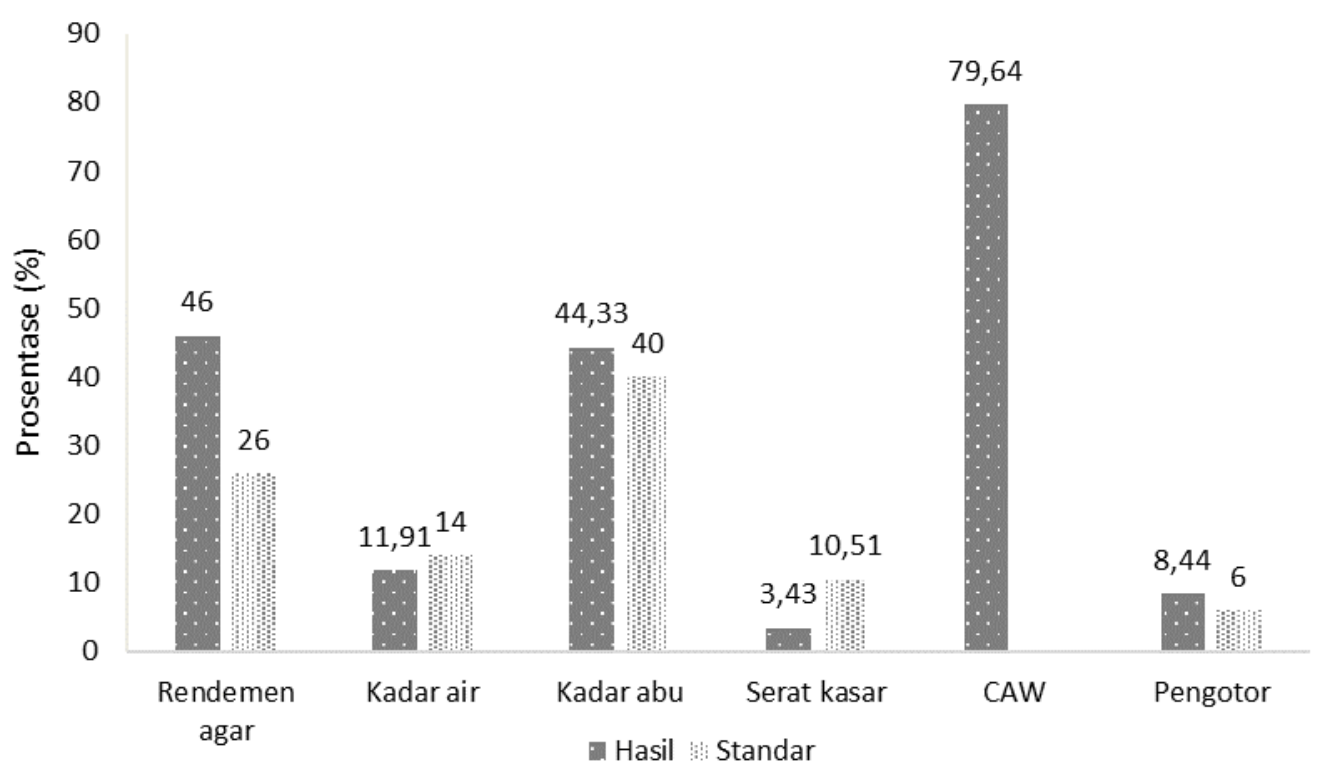

Gambar 2. Perbandingan Kualitas Rumput Laut Hasil Penelitian terhadap Standar Baku Mutu FAO 1987

Tabel 3. Hasil Analisis Data Kualitas Agar-agar

\begin{tabular}{clrcc}
\hline No & Parameter & Nilai & Satuan & Standart \\
\hline 1 & Viskositas & 201.6 & $\mathrm{cps}$ & \\
2 & Gel strenght & 354.76 & $\mathrm{~g} / \mathrm{cm}^{2}$ & $>600:$ Superior \\
& & & & $>350:$ Mutu 1 \\
& & & & $>250:$ Mutu 2 \\
& & & & $<150:$ Mutu 3 \\
& & 5.17 & $\%$ & $30 \%$ \\
3 & Derajat putih & 4.82 & $\%$ & $<6 \%$ \\
4 & Kadar sulfat & & & \\
\hline
\end{tabular}

\section{Kualitas Agar}

Agar merupakan polisakarida yang terakumulasi dalam dinding sel rumput laut penghasil agar atau agarofit, oleh karenanya kandungan agar yang terdapat dalam rumput laut di pengaruhi oleh musim (Armisen dan Galatas 2000).

\section{Viskositas}

Viskositas atau kekentalan didefinisikan sebagai perbandingan antara tekanan geser suatu cairan. Suspensi koloid dalam larutan dapat meningkatdengan cara mengentalkan cairan sehingga terjadi absorbsi dan pengembangan koloid
(Glicksman 1983). Rata-rata viskositas agar yang dihasilkan dalam penelitian ini berkisar antara 201.6 Cps.

Viskositas merupakan faktor kualitas yang penting untuk zat cair dan semi cair (kental) atau produk murni, dimana hal ini merupakan ukuran dan kontrol untuk mengetahui kualitas dari produk akhir (Joslyn 1970). Viskositas agar berpengaruh terhadap sifat gel terutama titik pembentukan gel dan titik leleh, dimana viskositas agar yang tinggi menghasilkan laju pelelehan dan pembentukan gel yang lebih tinggi dibanding agar yang viskositasnya rendah. 
Hasil penelitian Suryaningrum (1988) menyatakan bahwa peningkatan umur panen menurunan viskositas. Penurunan viskositas ini dipengaruhi oleh kandungan sulfat.Viskositas disebabkan oleh adanya daya tolak menolak antar grup sulfat yang bermuatan negatif disepanjang rantai polimernya, sehingga menyebabkan rantai polimer kaku dan tertarik kencang. Karena sifat hidrofilik menyebabkan molekul tersebut dikelilingi oleh air yang tidak bergerak, hal inilah yang menentukan nilai viskositas (Guiseley et al. 1980).

\section{Gel Strenght}

Parameter kualitas dari agar yang tidak kalah pentingnya adalah kekuatan gel dari agar itu sendiri yang banyak diperlukan dalam berbagai industri seperti industri makanan, makanan dalam kaleng, dan keperluan bioteknologi pada kultur mikroorganisme. Kekuatan gel yang dihasilkan dalam penelitian ini rata-rata $354.76 \mathrm{~g} / \mathrm{cm}^{2}$. Nilai kekuatan gel tertinggi yang didapatkan pada kedua metode penanaman yaitu pada kombinasi perlakuan bobot bibit $50 \mathrm{~g}$ dan umur panen 60 hari.

\section{Derajat Putih dan Kadar Sulfat}

Berdasarkan hasil analisis kualitas agar-agar Gracilaria verrucosa menunjukkan bahwa secara umum kualitas agar-agar cukup tinggi. Hal ini berdasarkan tingkat viskositas agar mencapai $201.6 \mathrm{cps}$ dan kekuatan gel strenght $356.76 \mathrm{~g} / \mathrm{cm}^{2}$. Apabila kualitas agar-agarhasil penelitian dibandingkan dengan standar kualitas agaragar di Jepang, maka kualitas agaragarhasil penelitian berada pada level Kualitas 1. Adapun berdasarkan standar agar-agar di Jepang, Gel Strenght Kualitas Superior $>600 \mathrm{~g} / \mathrm{cm}^{2}$, Kualitas $1>350$ $\mathrm{g} / \mathrm{cm}^{2}$, Kualitas $2>250 \mathrm{~g} / \mathrm{cm}^{2}$, Kualitas 3 $>150 \mathrm{~g} / \mathrm{cm}^{2}$ dan kualitas $4<150 \mathrm{~g} / \mathrm{cm}^{2}$. Kadar sulfat hanya mencapai $4.82 \%$. Kadar sulfat menunjukkan zat pengotor dalam kandungan agar-agar. Berdasarkan kandungan kadar sulfat agar-agar Gracilaria verrucosa, maka kualitas agar sangat tinggi, dimana syarat yang disarankan di Jepang, kadar sulfat harus $<6 \%$. Dengan demikian ternyata agaragarhasil penelitan termasuk bersih dan masuk pada level Kelas 1. Hasil analisis kualitas agar Gracilaria verrucosa di Kabupaten Karawang ditampilkan pada Tabel 3.

\section{KESIMPULAN}

Berdasarkan hasil analisis kualitas rumput laut Gracilaria verrucosa yang dibudidaya di tambak Kecamatan Tirtajaya menunjukkan bahwa konsentrasi rendemen agar dan kadar air menunjukkan kualitas rumput laut relatif cukup bagus, akan tetapi berdasarkan kategori kadar abu, serat kasar dan zat pengotor menunjukkan bahwa kualitas rumput laut di Kecamatan Tirtajaya relatif kurang bagus, hal ini ditunjukkan bahwa hasil analisis dari parameter tersebut berada di bawah standar yang dipersyaratkan.

Berdasarkan hasil analisis kualitas agar-agarGracilaria verrucosa menunjukkan bahwa secara umum kualitas agar-agar cukup tinggi. Hal ini berdasarkan tingkat viskositas agar mencapai $201.6 \mathrm{cps}$ dan kekuatan gel strenght $356.76 \mathrm{~g} / \mathrm{cm}^{2}$. Apabila kualitas agar-agarhasil penelitian dibandingkan dengan standar kualitas agaragar di Jepang, maka kualitas agaragarhasil penelitian berada pada level Kualitas 1. Adapun berdasarkan standar agar-agar di Jepang, Gel Strenght Kualitas Superior $>600 \mathrm{~g} / \mathrm{cm}^{2}$, Kualitas $1>350$ $\mathrm{g} / \mathrm{cm}^{2}$, Kualitas $2>250 \mathrm{~g} / \mathrm{cm}^{2}$, Kualitas 3 $>150 \mathrm{~g} / \mathrm{cm}^{2}$ dan kualitas $4<150 \mathrm{~g} / \mathrm{cm}^{2}$. Kadar sulfat hanya mencapai $4.82 \%$. Kadar sulfat menunjukkan zat pengotor dalam kandungan agar-agar. Berdasarkan kandungan kadar sulfat agaragarGracilaria verrucosa, maka kualitas agar sangat tinggi, dimana syarat yang disarankan di Jepang, kadar sulfat harus $<6 \%$. Dengan demikian ternyata agar- 
agarhasil penelitan termasuk bersih dan masuk pada level Kelas 1.

\section{DAFTAR PUSTAKA}

Anggadiredja J. 1998. Seaweed Diversity on the Warambadi Seashore of Sumba Island and list utilization. Master Degree Thesis University Indonesia

Armisén R, Galatas F. 2000. Agar. Di dalam Phillips GO, Williams PA (eds). Handbook of Hydrocolloids. England: Woodhead Publishing Limited.

[BSN] Badan Standardisasi Nasional. Standar Nasional Indonesia 2690:2015. Rumput Laut Kering Bagian 1: Spesifikasi. Jakarta (ID) : Badan Standardisasi Nasional.

[BSN] Badan Standardisasi Nasional. Standar Nasional Indonesia 2354.1:2010. Penentuan Kadar Abu dan Abu Tak Larut dalam Asam. Jakarta (ID) : Badan Standardisasi Nasional.

[BSN] Badan Standardisasi Nasional (BSN). 1998. Standar Nasional Indonesia Rumput Laut Kering, SNI No.2690.01 : 1998, Jakarta.

Cirik Ş, Cetin Z, Ak I, Cirik S, Goksan T. 2010. Greenhouse Cultivation of Gracilaria verrucosa (Hudson) Papenfuss and Determination of Chemical Composition. Turk. J. Fish. Aquat. Sci. 10: 559-564

Glicksman M. 1982. Food Hydrocolloids. Vol. I. CRC Press, Inc. Boca Raton. Florida. 219

Guiseley KB, Stanley NF, White House PA. 1980. Carrageenan. Dalam Davids RL (ed). Handbook of Water Soluable Gums and Resins. NY Toronto, Lindon: Mc Graw Hill Book Company.
Joslyn MA. 1970. Ash content ashing procedures. Dalam MA Joslyn.Methods in Food Analysis. $2^{\text {nd }}$ edition. Academic Press. New York: San Fransisco

Marinho-Soriano E, Fonseca PC, Carneiro MAA and Moreira W S C. 2006. Seasonal variation in the chemical composition of two tropical seaweeds. Biores. Technol., 97, 2402-2406.

McHugh DJ. 2003. A Guide to The Seaweed Industry FAO Fisheries Technical Paper 441. Canberra (AU) : University of New South Wales and Australian Defence Force Academy Canberra Australia.

Ova-Kaykac G. 2007. Seasonal variation of taste active components in some seaweeds (Cystoseira barbata, Ulva rigida and Gracilaria verrucosa). MSc. thesis. Çanakkale: Onsekiz Mart University

Palegrin YF, Murano E. 2005. Agars from three species of Gracilaria (Rhodophyta) from Yucatan Peninsula. J Bioresources Technology, 96(2005): 295-302.pp.

Soegiarto A, Sulistijo, Atmadja WS, Mubarak H. 1978. Rumput Laut (Alga): Manfaat, Potensi, dan Usaha Budidayanya. Jakarta: LIPI.

Sukomulyo S. 1989. Mempelajari cara ekstraksi dengan praperlakuan asam dalam pembuatan agar-agar dari Gelidium sp. [skripsi]. Bogor (ID) : Institut Pertanian Bogor.

Suryaningrum TD. 1988. Kajian Sifat-sifat Mutu Rumput Laut Budidaya Eucheuma cottonii dan Eucheuma spinosum. Tesis. Fakultas Pascasarjana IPB. Bogor 
Wenno MR, Johanna L, Thenu dan Cynthia GCL. 2012. Karakteristik Kappa Karaginan dari Kappaphycus alvarezii pada Berbagai Umur Panen. JPB Perikanan Vol. 7 No. 1 hal: 61-68

Yousefi MK, Islami HR, Filizadeh Y. 2013. Effect of extraction process on agar properties of Gracilaria corticata (Rhodophyta) collected from the Persian Gulf. Phycologia $52(5): 1-7$. 